\title{
Soil Available Phosphorus Investigated for Spatial Distribution and Effect Indicators Resulting from Ecological Construction on the Loess Plateau, China
}

\author{
Shengdong Cheng ${ }^{1,2, *}$, Ganggang $\mathrm{Ke}^{1,2}$, Zhanbin $\mathrm{Li}^{1,2}$, Yuting Cheng ${ }^{3}$ and Heng $\mathrm{Wu}^{1,2}$ \\ 1 State Key Laboratory of Eco-Hydraulics in Northwest Arid Region, Xi'an University of Technology, \\ Xi'an 710048, China; ganggangkerum@163.com (G.K.); zhanbinli@126.com (Z.L.); wuheng9699@163.com (H.W.) \\ 2 Key Laboratory of National Forestry Administration on Ecological Hydrology and Disaster Prevention in \\ Arid Regions, Xi'an University of Technology, Xi'an 710048, China \\ 3 College of Life Science, Yan'an University, Yan'an 716000, China; chengyutingstar@163.com \\ * Correspondence: xautcsd@163.com; Tel.: +86-29-8231-651
}

Citation: Cheng, S.; Ke, G.; Li, Z.; Cheng, Y.; Wu, H. Soil Available Phosphorus Investigated for Spatial Distribution and Effect Indicators Resulting from Ecological Construction on the Loess Plateau, China.

Sustainability 2021, 13, 12572. https:// doi.org/10.3390/su132212572

Academic Editor: Andres Seco Meneses

Received: 16 October 2021

Accepted: 10 November 2021

Published: 14 November 2021

Publisher's Note: MDPI stays neutral with regard to jurisdictional claims in published maps and institutional affiliations.

Copyright: (c) 2021 by the authors. Licensee MDPI, Basel, Switzerland. This article is an open access article distributed under the terms and conditions of the Creative Commons Attribution (CC BY) license (https:/ / creativecommons.org/licenses/by/ $4.0 /)$.

\begin{abstract}
Soil phosphorus is a major determinant and indicator of soil fertility and quality, and is also a source of nonpoint-source pollution. In order to control soil and water loss in the Loess Plateau, a series of soil and water conservation measures have been taken, resulting in changes in land use and differences in spatial distribution. It is necessary to study soil available phosphorus (SAP) to evaluate land productivity and environmental quality. In this study, the spatial distribution of SAP in different land uses was investigated in a small catchment area of Loess Plateau, and the field-influencing factors were determined on five layers with soil depth of $20 \mathrm{~cm}$. The results show the minimum and maximum SAP content occurred at $20-40 \mathrm{~cm}$ and $80-100 \mathrm{~cm}$ soil depth and reach a value of $27.26 \mathrm{mg} / \mathrm{kg}$ and $29.37 \mathrm{mg} / \mathrm{kg}$ at catchment scale, respectively. There is significant difference among the SAP of the five soil layers $(p<0.01)$. The SAP of different land uses is, in order: forestland < slope farmland $<$ dam farmland $<$ terrace $<$ grassland Different land uses' topographies make a difference to the spatial distribution of SAP. Slope and soil texture are the domain factors influencing the SAP concentration at the catchment.
\end{abstract}

Keywords: soil available phosphorus; land use change; vegetation restoration; check dam; terrace

\section{Introduction}

As an important part of the soil, phosphorus is an extremely important ecological factor in terrestrial and aquatic ecosystems, and also a necessary nutrient element for the life activities of animals and plants [1]. In terrestrial ecosystems, the soil phosphorus level is closely related to soil productivity, for it directly affects soil fertility and crop growth quality. Availability of phosphorus $(\mathrm{P})$ can directly and/or indirectly affect nitrogen $(\mathrm{N})$ retention and loss from soil by stimulating microbial and plant root activities [2]. In recent years in the agricultural ecosystem, in order to increase soil fertility and increase crop yields, a large amount of chemical fertilizers has been artificially thrown into the soil, which has in essence led to the enrichment of phosphorus in terrestrial ecosystems [3]. Excessive enrichment of phosphorus can change the effectiveness of nutrients and increase the number and activity of microorganisms [4]. At the same time, large amounts of phosphorus emitted due to agricultural production causes water eutrophication $[5,6]$, endangering the water supply ecosystem and human health. Land use changes caused by human factors and climate change also have important impacts on the content changes of soil available phosphorus (SAP). Changes in land use patterns often lead to changes in the soil phosphorus cycle pattern, affecting the stability and sustainability of the entire ecosystem [7]. Irrational land use can lead to serious soil erosion and environmental problems, for instance, water eutrophication arising from the loss of soil nutrients [8]. In the meanwhile, frequent changes in land use structure will also conflict with the ecological environment [9], resulting in a series of serious consequences, such as increasing soil loss; reducing the content of organic 
matter, nitrogen, and phosphorus in soil; as well as impairing soil fertility [10]. Plant cover significantly reduced available $P$ losses in experimental fields [11]. However, appropriate soil and water conservation measures can significantly decrease soil erosion and nutrient loss, especially in the Loess Plateau, which is ecologically fragile and vulnerable to erosion [12]. In order to control soil erosion and restore ecosystems, the Chinese government launched a series of ecological construction projects in the Loess Plateau in 1999 with the purpose of rationally utilizing land resources according to local conditions and restoring forest vegetation [13]. As the main water conservation measures, slope-transformed terraces, check dams, and "returning the farmland to forestry (grass)" are considered as breakthroughs and basic guarantees for the restoration of ecological construction. So far, more than $16,000 \mathrm{~km}^{2}$ of sloping cropland has been converted into forest (grass) land, so that the vegetation coverage of the Loess Plateau has increased by $25 \%$ [14]. Furthermore, 5470 large check dams and 52,444 small and medium ones had been built by the end of 2011 . As of 2012, the total terrace area of the Loess Plateau was 3,712,900 $\mathrm{hm}^{2}$, the ability of which to reduce sand was about 500 million tons [15]. This large-scale ecological construction has not only altered the vegetation, soil properties, and land structure of the Loess Plateau, but also created a certain influence on the nutrient circulation in the Loess Plateau [16]. In that case, it is of immense significance to accurately assess the changes of soil phosphorus content after ecological construction, to analyze its reserves in different land uses, and to find out its spatial distribution and evolution rules. Currently, most studies focus on the effects of land use changes on soil carbon and nitrogen distribution [17,18], yet very few reports emphasize the spatial distribution of soil phosphorus and its influencing factors, let alone that in small watersheds.

Small watersheds are likely to be the sources of multiple rivers. The nutrients carried by runoff and sediment often result in the eutrophication of rivers and lakes in watersheds, as well as the degradation of water quality. For that reason, it is of tremendous importance to study the spatial distribution of SAP and its influencing factors for understanding the changes of the soil phosphorus cycle and water quality in the basin. This article has selected a typical small watershed in the Loess Plateau to analyze the spatial distribution of SAP and the influencing topographic factors, for which the principal objectives are (1) to assess the impact of ecological construction on the spatial distribution and reserves of SAP, and (2) to analyze the influence of topographic factors on SAP content at different soil depths.

\section{Materials and Methods}

\subsection{Study Area}

The study area is located in the Wangmaogou Basin $\left(110^{\circ} 20^{\prime} 26^{\prime \prime}-110^{\circ} 22^{\prime} 46^{\prime \prime} \mathrm{E}\right.$, $37^{\circ} 34^{\prime} 13^{\prime \prime}-37^{\circ} 36^{\prime} 03^{\prime \prime}$ N) of the Loess Plateau, and in the Wuding River Basin $5 \mathrm{~km}$ north of Suide County, Shaanxi Province, China (Figure 1). The area of the watershed is $5.97 \mathrm{~km}^{2}$, the altitude is between $936 \mathrm{~m}$ and $1188 \mathrm{~m}$, and the annual average temperature is $10.2{ }^{\circ} \mathrm{C}$. The average annual precipitation in this area is about $513 \mathrm{~mm}$, which is unevenly distributed during the year, and the rainfall from July to September makes up $60 \%$ of the entire year. The soil is dominated by loessal soil. The loess has developed vertical joints and uniform particles, but the clay content is low and the cementation is weak, which can easily cause serious soil erosion when affected by rainfall during the flood season. Since 1950, many water and soil conservation measures have been implemented in the Wangmaogou Basin, and therefore this basin can be used as a typical watershed for water and soil conservation research. The main types of land use in the basin are sloping cropland $(22.32 \%)$, forestland $(9.15 \%)$, grassland $(36.51 \%)$, terrace $(25.78 \%)$, and check dam $(6.24 \%)$. 


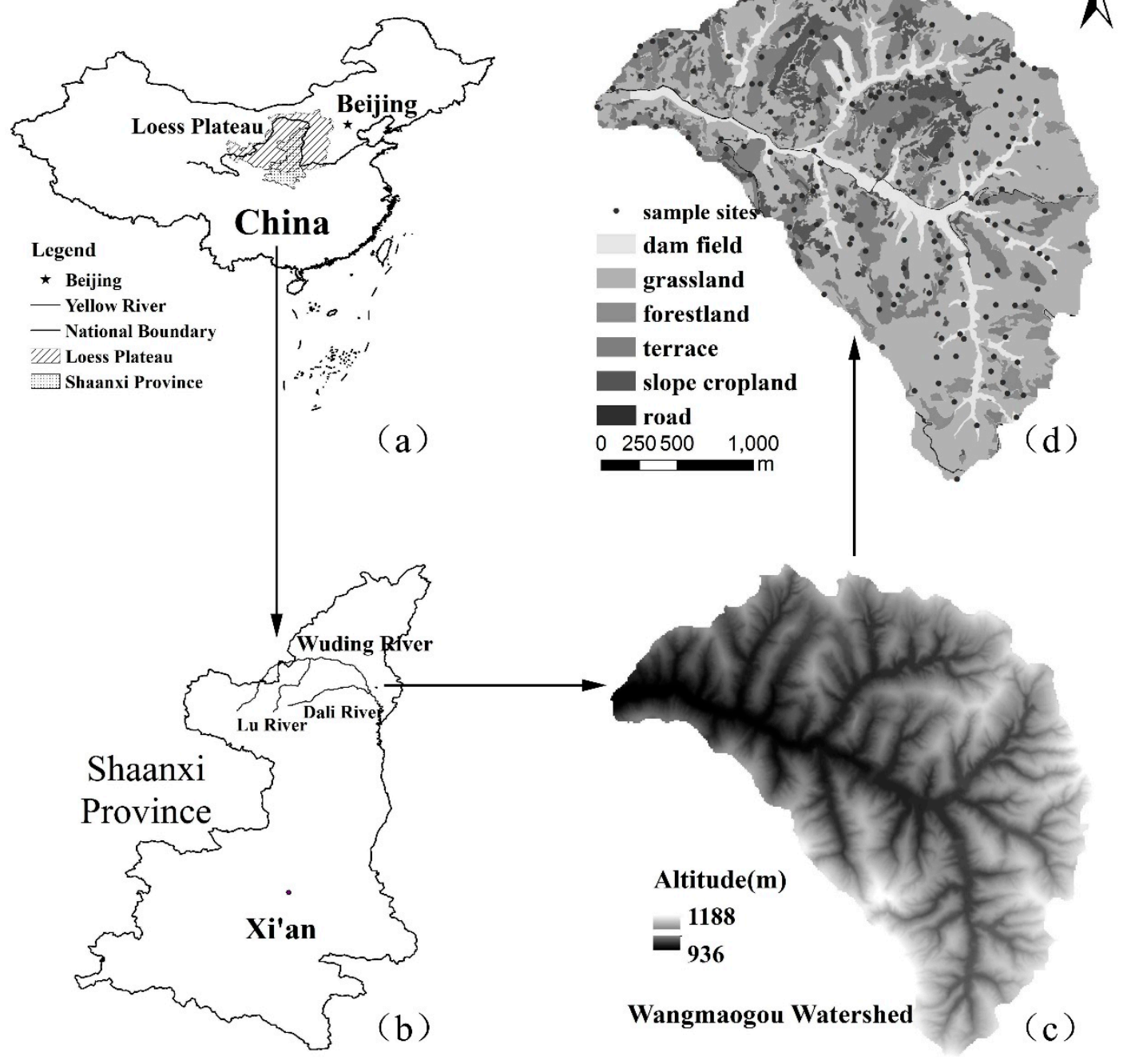

Figure 1. Location map of the Loess Plateau in China (a), Location map of Wuding River in Shaanxi Province (b), The Digital Elevation Model of the Wangmaogou watershed (c), Land use types (d), The sampling point distribution (d) (The direction of the arrow is the layout of the study area from large to small in China).

\subsection{Methods}

2.2.1. Soil Sample Collection and Determination Methods

Soil samples were collected from July to August in 2014 by using a drill with a diameter of $6.9 \mathrm{~cm}$. The sampling depth was $100 \mathrm{~cm}$, and soil samples from each soil layer were collected at depths of $0-20 \mathrm{~cm}, 20-40 \mathrm{~cm}, 40-60 \mathrm{~cm}, 60-80 \mathrm{~cm}$, and $80-100 \mathrm{~cm}$. The average interval for each sample point was $100 \mathrm{~m}$. The numbers of soil samples collected under different land use patterns were 18 (terrace), 114 (grassland), 48 (forestland), 20 (sloping cropland), and 16 (check dam). In the process of collecting soil samples, the altitude, gradient, slope aspect, vegetation type, and coverage of sampling points have also been recorded. The analysis of SAP used a fully automated intermittent analyzer. The soil bulk density was measured with a ring knife. A total of 15 soil profiles were taken in the sloping cropland, forestland, grassland, terrace, and check dam, which were $60 \mathrm{~cm}$ deep, sampled at $20 \mathrm{~cm}$ intervals, and brought back to the laboratory oven at $105^{\circ} \mathrm{C}$. The soil bulk density was measured after $10 \mathrm{~h}$ of drying. Soil thicknesses of 0-20 cm, 20-40 cm, 40-60 cm, 60-80 cm, and 80-100 cm are indicated by A1, A2, A3, A4, and A5, respectively. 


\subsubsection{Data Analysis and Processing Methods}

The descriptive statistical analysis is performed by SPSS (20.0) software, the semivariance function is calculated by GS + (7.0), and the spatial distribution map is produced by ArcGIS (10.1).

The semi-variance function is a key function for studying the spatial variability of soil in geostatistics. Its theoretical model can be applied to analyze the randomness and structure of the spatial variability of SAP. It is expressed by Equation (1), as follows [19]:

$$
\gamma(h)=\frac{1}{2 N(h)} \sum_{i=1}^{N(h)}\left[z\left(x_{i}\right)-z\left(x_{i}+h\right)\right]^{2}
$$

In Equation (1), $\gamma(h)$ is the semi-variance function; $z\left(x_{i}\right)-z\left(x_{\mathrm{i}}+h\right)$ is the measured value of two observation points with interval $h ; N(h)$ is the pair number of all observation points in steps of $h$. The semi-variance function diagram is usually obtained by plotting $\gamma(h)$ in line with $h$. Usually, the value of the semi-variance function increases with the distance from the sample points, and increases to a substantially stable constant within a certain range of variation, namely the base value. A reasonable theoretical model can be obtained by fitting the semi-variance function according to the determination coefficient $\mathrm{R} 2$ and the residual RSS.

The calculation of SAP reserves uses the calculation formula of soil organic carbon reserves [20]:

$$
\begin{gathered}
C_{i}=d_{i} \times \rho_{i} \times O_{i} / 100 \\
W_{i}=A_{i} \times C_{i}
\end{gathered}
$$

In the formula, $i$ is different levels of soil; $C$ is SAP density $\left(\mathrm{g} / \mathrm{m}^{2}\right) ; d$ is the thickness of soil $(\mathrm{cm}) ; p$ is soil bulk density $\left(\mathrm{g} / \mathrm{cm}^{3}\right), O$ is SAP content $(\mathrm{mg} / \mathrm{kg}) ; A$ is the area occupied by each type; and $W$ is SAP reserves.

\section{Results}

\subsection{Statistical Characteristics of SAP}

As can be seen from Table 1, the available phosphorus content in different soil depths was tested by ANOVA, and there is a significant difference in SAP at different soil depths $(p<0.01)$, which is huge between the minimum and maximum values, close to 50 times. The maximum average value is in layer A5, and the minimum in layer A2, which are $29.37 \mathrm{mg} / \mathrm{kg}$ and $27.26 \mathrm{mg} / \mathrm{kg}$, respectively. The variations of available phosphorus are from $35 \%$ in the A5 layer to $38 \%$ in the A4 layer. According to the classification system proposed by Nielson and Bouma [21] (pp. 170-175), the weak variation CV is $\leq 10 \%$; the moderate variation is $10 \%<\mathrm{CV}<100 \%$; and the strong variation $\mathrm{CV}$ is $\geq 100 \%$. Consequently, the variation coefficients of available phosphorus in all five soil layers are moderately variable.

Table 1. Statistical characteristics of SAP at different depths $(\mathrm{mg} / \mathrm{kg})$.

\begin{tabular}{ccccccccc}
\hline $\begin{array}{c}\text { Layer } \\
\text { Depth (cm) }\end{array}$ & $\begin{array}{c}\text { Mean } \\
\text { Value }\end{array}$ & $\begin{array}{c}\text { Standard } \\
\text { Deviation }\end{array}$ & Min. & Max. & Skewness & Kurtosis & K-S (p) & CV (\%) \\
\hline A1 & 28.19 & 10.27 & 1.14 & 50.4 & -0.39 & -0.19 & 0.52 & 36 \\
A2 & 27.26 & 10.12 & 1.17 & 50.72 & -0.45 & -0.26 & 0.35 & 37 \\
A3 & 28.4 & 10.56 & 0.7 & 54.57 & -0.15 & -0.03 & 0.48 & 37 \\
A4 & 27.66 & 10.54 & 0.52 & 57.15 & -0.24 & -0.05 & 0.87 & 38 \\
A5 & 29.37 & 10.21 & 2.62 & 59.25 & -0.15 & 0.43 & 0.71 & 35 \\
\hline
\end{tabular}

For geostatistical analysis, since the Kriging method has the highest prediction accuracy for normal distribution data, it is indispensable to test whether the data set of SAP satisfies normal distribution before conducting geostatistical analysis. From the K-S test and the skewness and kurtosis, it can be discovered that the SAPs in the five soil layers all 
obey the normal distribution $(p>0.05)$ and meet the requirements of the next-step analysis.

The normal distribution curve is shown in Figure 2.
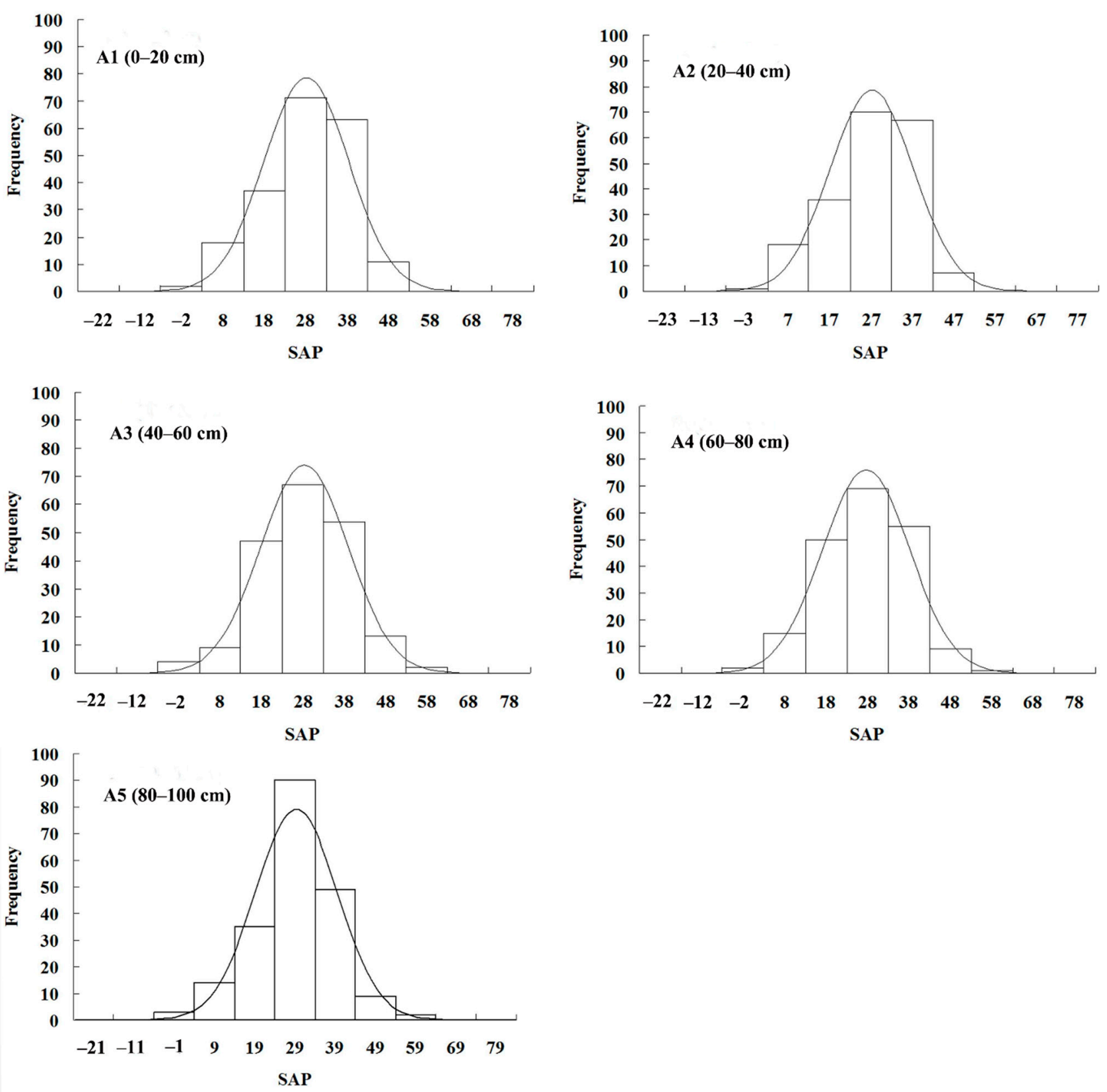

Figure 2. Normal distribution curve of soil available phosphorus in 0 20 cm layer (A1); Normal distribution curve of soil available phosphorus in 20 40 cm layer (A2); Normal distribution curve of soil available phosphorus in 40 60 cm layer (A3); Normal distribution curve of soil available phosphorus in 60 80 cm layer (A4); Normal distribution curve of soil available phosphorus in 80 100 cm layer (A5).

\subsection{Changes of SAP and Bulk Density with Different Land Uses}

Dual-factor ANOVA has shown that land use and soil depth significantly affect SAP content $(p<0.01)$. Table 2 contains the average SAP content and bulk density under different land uses, from which the average SAP content of the five land types in a descending order is: grassland $>$ terrace $>$ check dam $>$ sloping cropland $>$ forestland. The SAP content in the terrace and dam of layer A1 is dramatically higher than other lands. The soil bulk density under different land uses shows that: grassland $>$ terrace $>$ sloping cropland $>$ forestland $=$ dam. 
Table 2. Mean values and bulk density of SAP under different land uses.

\begin{tabular}{|c|c|c|c|c|c|c|c|c|c|c|}
\hline \multirow[b]{2}{*}{$\begin{array}{l}\text { Layer } \\
\text { Depth } \\
(\mathrm{cm})\end{array}$} & \multicolumn{2}{|c|}{ Terrace } & \multicolumn{2}{|c|}{ Grassland } & \multicolumn{2}{|c|}{ Forestland } & \multicolumn{2}{|c|}{ Sloping Cropland } & \multicolumn{2}{|c|}{ Check Dam } \\
\hline & $\begin{array}{c}\text { SAP } \\
(\mathrm{mg} / \mathrm{kg})\end{array}$ & $\begin{array}{c}\text { Bulk } \\
\text { Density } \\
\left(\mathrm{g} / \mathrm{cm}^{3}\right)\end{array}$ & $\begin{array}{c}\text { SAP } \\
(\mathrm{mg} / \mathrm{kg})\end{array}$ & $\begin{array}{c}\text { Bulk } \\
\text { Density } \\
\left(\mathrm{g} / \mathrm{cm}^{3}\right)\end{array}$ & $\begin{array}{c}\text { SAP } \\
(\mathrm{mg} / \mathrm{kg})\end{array}$ & $\begin{array}{c}\text { Bulk } \\
\text { Density } \\
\left(\mathrm{g} / \mathrm{cm}^{3}\right)\end{array}$ & $\begin{array}{c}\text { SAP } \\
(\mathrm{mg} / \mathrm{kg})\end{array}$ & $\begin{array}{c}\text { Bulk } \\
\text { Density } \\
\left(\mathrm{g} / \mathrm{cm}^{3}\right)\end{array}$ & $\begin{array}{c}\text { SAP } \\
(\mathrm{mg} / \mathrm{kg})\end{array}$ & $\begin{array}{c}\text { Bulk } \\
\text { Density } \\
\left(\mathrm{g} / \mathrm{cm}^{3}\right)\end{array}$ \\
\hline A1 & 30.53 & 1.28 & 28.95 & 1.26 & 26.52 & 1.27 & 28.51 & 1.29 & 30.7 & 1.37 \\
\hline A2 & 28.6 & 1.35 & 28.33 & 1.35 & 24.85 & 1.28 & 26.83 & 1.36 & 27.12 & 1.17 \\
\hline A3 & 29.24 & 1.34 & 29.19 & 1.4 & 26.87 & 1.32 & 25.3 & 1.32 & 27.04 & 1.33 \\
\hline $\mathrm{A} 4$ & 28.15 & - & 29.5 & - & 24.59 & - & 26.12 & - & 24.94 & - \\
\hline A5 & 29.06 & - & 29.97 & - & 26.73 & - & 25.36 & - & 25.09 & - \\
\hline $\begin{array}{l}\text { Mean } \\
\text { Value }\end{array}$ & 29.11 & 1.32 & 29.19 & 1.34 & 25.84 & 1.29 & 26.42 & 1.32 & 26.98 & 1.29 \\
\hline
\end{tabular}

\subsection{Relationship between SAP Content and Topographic Factors}

Table 3 shows the average SAP content of different land uses under topographic factors. According to the actual situation in the study area, the altitude is composed of 4 levels, $\leq 1000 \mathrm{~m}, 1000-1050 \mathrm{~m}, 1050-1100 \mathrm{~m}$, and $>1100 \mathrm{~m}$; the slope consists of 6 levels, flat slope $\left(0-3^{\circ}\right)$, slight slope $\left(3-8^{\circ}\right)$, slope $\left(8-15^{\circ}\right)$, slightly steep slope $\left(15-25^{\circ}\right)$, steep slope $\left(25-35^{\circ}\right)$, and extremely steep slope $\left(>35^{\circ}\right)$; and, the slope aspect is divided into shady slope and sunny slope [22]. The effect of topographic factors on SAP content is considerably different under different land use conditions. In light of the ANOVA analysis, there is a substantial correlation between altitude and SAP content in terrace, grassland, and sloping cropland $(p<0.01)$, but the correlation between altitude and SAP content in dam and forestland is not evident $(p>0.05)$. The relationship between gradient and SAP content in grassland, forestland, and sloping cropland is striking $(p<0.01)$; however, the slope aspect only has a distinct correlation with the SAP content in forestland $(p<0.05)$, but not in other land uses $(p>0.05)$.

Table 3. Average SAP content in different land uses under topographic factors.

\begin{tabular}{|c|c|c|c|c|c|c|c|c|c|c|c|c|c|}
\hline \multirow{2}{*}{\multicolumn{2}{|c|}{ Terrain Factors }} & \multicolumn{6}{|c|}{ Gradient $\left(^{\circ}\right)$} & \multicolumn{4}{|c|}{ Altitude (m) } & \multicolumn{2}{|c|}{ Slope Aspect } \\
\hline & & $0-3$ & $3-8$ & 8-15 & $15-25$ & $25-35$ & $>35$ & $\leq 1000$ & $\begin{array}{l}1000- \\
1050\end{array}$ & $\begin{array}{l}1050- \\
1100\end{array}$ & $>1100$ & $\begin{array}{l}\text { Sunny } \\
\text { Slope }\end{array}$ & $\begin{array}{l}\text { Shady } \\
\text { Slope }\end{array}$ \\
\hline \multirow{5}{*}{$\begin{array}{c}\text { Check } \\
\text { Dam }\end{array}$} & A1 & 26.26 & - & - & - & - & - & 29.78 & 31.49 & - & - & 30.7 & - \\
\hline & A2 & 23.91 & - & - & - & - & - & 29.5 & 25.07 & - & - & 27.12 & - \\
\hline & A3 & 29.5 & - & - & - & - & - & 27.42 & 26.72 & - & - & 27.04 & - \\
\hline & A4 & 23.96 & - & - & - & - & - & 25.57 & 24.4 & - & - & 24.94 & - \\
\hline & A5 & 28.8 & - & - & - & - & - & 28.06 & 22.56 & - & - & 25.09 & - \\
\hline \multirow{5}{*}{ Terrace } & A1 & 29.66 & - & - & - & - & - & 32.53 & 33.91 & 28.28 & 9.66 & 28.6 & 30.35 \\
\hline & A2 & 27.57 & - & - & - & - & - & 32.72 & 30.86 & 25.62 & 11.42 & 27.62 & 27.54 \\
\hline & A3 & 28.31 & - & - & - & - & - & 30.71 & 32.26 & 27.15 & 9.57 & 30.69 & 26.76 \\
\hline & A4 & 27.91 & - & - & - & - & - & 31.55 & 29.02 & 28.67 & 14.68 & 27.61 & 28.1 \\
\hline & A5 & 29.49 & - & - & - & - & - & 29.18 & 31.33 & 31.82 & 12.21 & 29.24 & 29.66 \\
\hline \multirow{5}{*}{ Grassland } & A1 & - & 27.59 & 30.86 & 27.42 & 27.48 & 31.63 & 38 & 28.8 & 29.7 & 26.84 & 28.88 & 29.2 \\
\hline & A2 & - & 31.63 & 29.12 & 27.26 & 25.18 & 31.53 & 38.05 & 29.6 & 27.18 & 26.45 & 27.33 & 28.94 \\
\hline & A3 & - & 29.73 & 33.05 & 25.85 & 29.98 & 29.56 & 35.46 & 29.13 & 29.99 & 26.5 & 29.32 & 28.99 \\
\hline & A4 & - & 25.06 & 31.82 & 26.17 & 28.59 & 31.12 & 34.86 & 29.03 & 30.99 & 24.16 & 29.05 & 28.85 \\
\hline & A5 & - & 29.69 & 33.04 & 29.89 & 27.43 & 32.65 & 37.5 & 30.61 & 30.11 & 29.04 & 30.3 & 30.36 \\
\hline \multirow{5}{*}{ Forestland } & A1 & 25.28 & 22.28 & 22.31 & 28.9 & 19.89 & 27.65 & 27.94 & 26.39 & 28.38 & 22.43 & 25.8 & 24.86 \\
\hline & A2 & 6.53 & 19.02 & 22 & 30.19 & 22.69 & 27.69 & 31.71 & 25.66 & 23.44 & 23.57 & 26.03 & 23.14 \\
\hline & A3 & 0.7 & 25.33 & 20.06 & 36.15 & 19.06 & 31.25 & 27.38 & 28.78 & 24.67 & 27.22 & 27.64 & 26.6 \\
\hline & A4 & 26.69 & 21.79 & 20.27 & 29.26 & 21.76 & 27.43 & 24.37 & 25.34 & 25.24 & 25.13 & 26.6 & 22.72 \\
\hline & A5 & 16.37 & 31.69 & 21.49 & 34.16 & 28.48 & 30.08 & 35.83 & 26.41 & 27.09 & 30.07 & 31.69 & 23.69 \\
\hline \multirow{5}{*}{$\begin{array}{l}\text { Sloping } \\
\text { Cropland }\end{array}$} & A1 & - & 33.1 & 27.2 & 28.05 & 21.34 & 27.06 & 31.14 & 21.18 & 22.72 & 30.95 & 25.51 & 25.94 \\
\hline & $\mathrm{A} 2$ & - & 26.18 & 27.45 & 28.29 & 26.04 & 27.56 & 30.59 & 23.32 & 27.84 & 26.06 & 27.89 & 26.68 \\
\hline & A3 & - & 31.87 & 23.82 & 27.44 & 23.37 & 19.28 & 26.52 & 20.35 & 27.86 & 30.79 & 26.5 & 24.53 \\
\hline & A4 & - & 24.22 & 29.33 & 30.58 & 21.48 & 30.69 & 30.99 & 19.69 & 30.13 & 24.5 & 22.31 & 28.44 \\
\hline & A5 & - & 29.72 & 31.18 & 26.83 & 21.32 & 21.06 & 24.35 & 22.44 & 26.3 & 31.62 & 22.66 & 25.98 \\
\hline
\end{tabular}




\subsection{Geostatistics Analysis of SAP}

Table 4 shows the geostatistical parameters of SAP at different soil depths. The model with the highest fitting degree (R2) and the smallest residual sum of squares (RSS) is selected as the optimal model (Figure 3). Under the five soil layers, the optimal models of SAP are all linear models, whose determination coefficients are $0.861,0.941,0.859,0.71$, and 0.867 , and the RSS is also smaller, indicating that the model has high fitting accuracy and can well reflect the spatial structure characteristics of SAP in the study area. The nugget coefficient represents the degree of spatial correlation of system variables. When the ratio is $<25 \%$, the system has a strong spatial correlation; $25-75 \%$, a medium spatial correlation; and $>75 \%$, a weak spatial correlation. The nugget coefficients of SAP of all layers are relatively large, accounting for $50-81 \%$, indicating that the spatial variability of SAP is mainly attributed to structural and random factors. Structural factors such as climate, parent material, topography, soil type, and other natural factors can lead to strong spatial correlation of soil nutrients; while random factors such as fertilization, farming measures, cropping systems, and other human activities undermine spatial correlation of SAP, thus developing in the direction of homogenization. The variations of the five soil depths (194-493 m) are larger than the grid sampling interval of $100 \mathrm{~m}$ used in this research and satisfy the spatial analysis requirements.

Table 4. Geostatistical parameters of SAP at different depths.

\begin{tabular}{cccccccc}
\hline $\begin{array}{c}\text { Layer } \\
\text { Depth }\end{array}$ & C0 & C0 + C & $\begin{array}{c}\text { Nugget } \\
\text { Coefficient } \\
\text { GD (\%) }\end{array}$ & $\begin{array}{c}\text { Variation } \\
\text { Amplitude } \\
(\mathbf{m})\end{array}$ & Model & R2 & $\begin{array}{c}\text { Residual } \\
\text { RSS }\end{array}$ \\
\hline A1 & 49 & 98 & 50 & 424 & Spherical & 0.861 & 205 \\
A2 & 28.7 & 90.35 & 68 & 194 & Gaussian & 0.941 & 170 \\
A3 & 20.8 & 108.8 & 81 & 308 & Spherical & 0.859 & 410 \\
A4 & 21.1 & 106.2 & 80 & 322 & Spherical & 0.71 & 1068 \\
A5 & 53.5 & 110 & 51 & 493 & Spherical & 0.867 & 285 \\
\hline
\end{tabular}
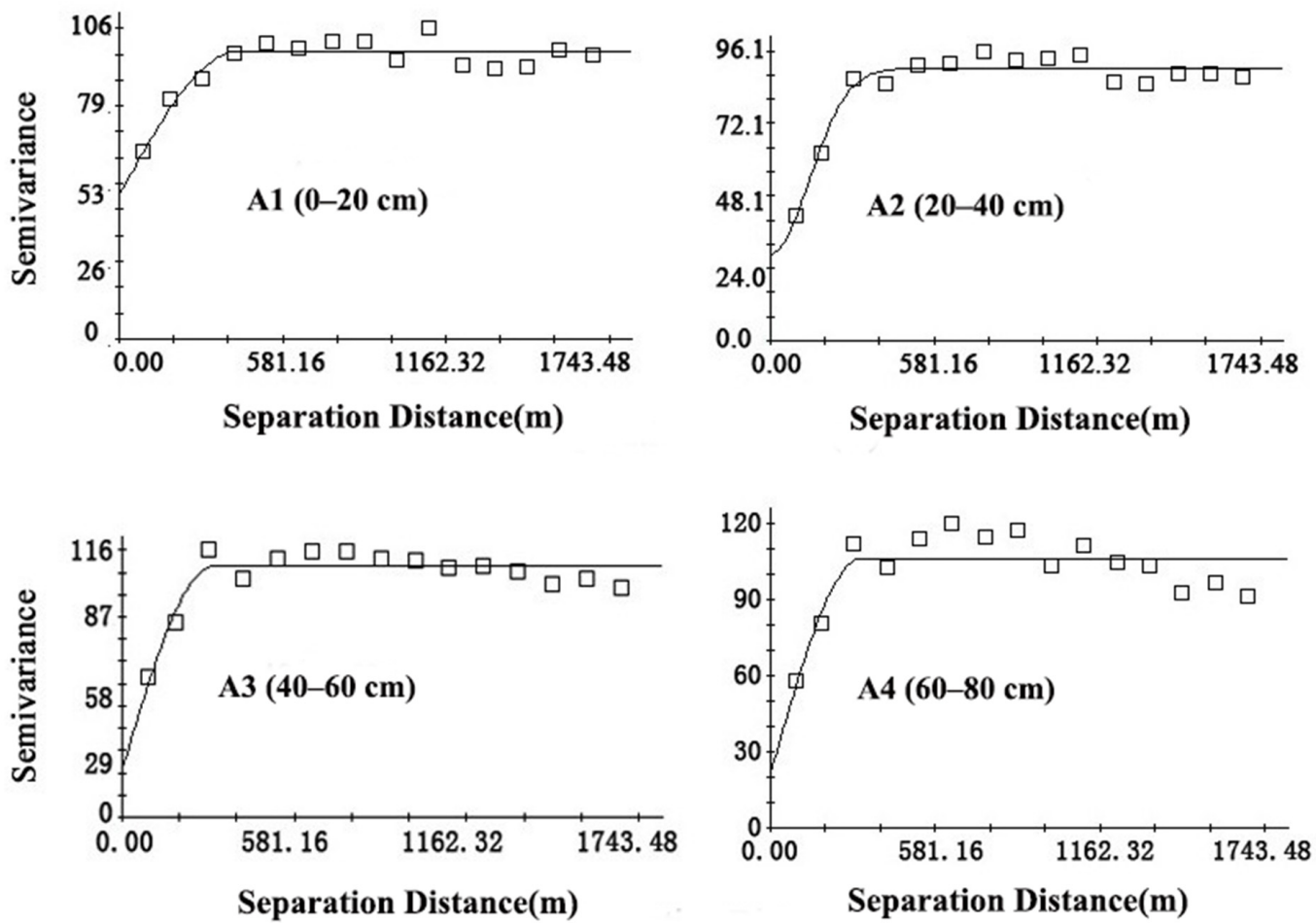

Figure 3. Cont. 


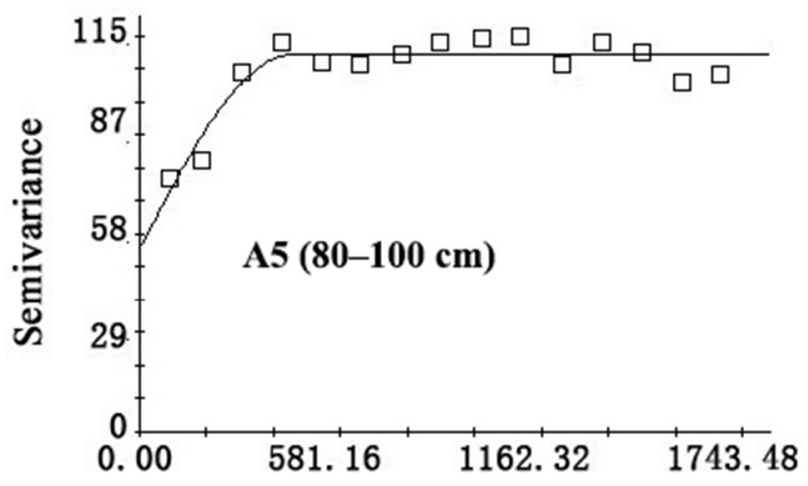

\section{Separation Distance(m)}

Figure 3. Semi variance function theoretical model of available phosphorus in $0 \sim 20 \mathrm{~cm}$ soil layer (A1); Semi variance function theoretical model of available phosphorus in $20 \sim 40 \mathrm{~cm}$ soil layer (A2); Semi variance function theoretical model of available phosphorus in $40 \sim 60 \mathrm{~cm}$ soil layer (A3); Semi variance function theoretical model of available phosphorus in $60 \sim 80 \mathrm{~cm}$ soil layer (A4); Semi variance function theoretical model of available phosphorus in $80 \sim 100 \mathrm{~cm}$ soil layer (A5).

\subsection{Spatial Distribution of SAP}

Kriging interpolation is applied to the SAP values at five sampling depths, plotting the spatial distribution of SAP in the five soil layers of Wangmaogou Basin (Figure 4). It can be seen from the figure that the SAP in the five soil layers shows a patchy distribution. As the depth increases, the available phosphorus content gradually decreases, and so does the change range of the available phosphorus. The SAP content in layer A1 is the highest and in layer A5 is the lowest. The highest SAP is generally at the intersection of rivers, such as grassland and dam land. Hence, the spatial distribution characteristics of SAP are closely related to land use types.
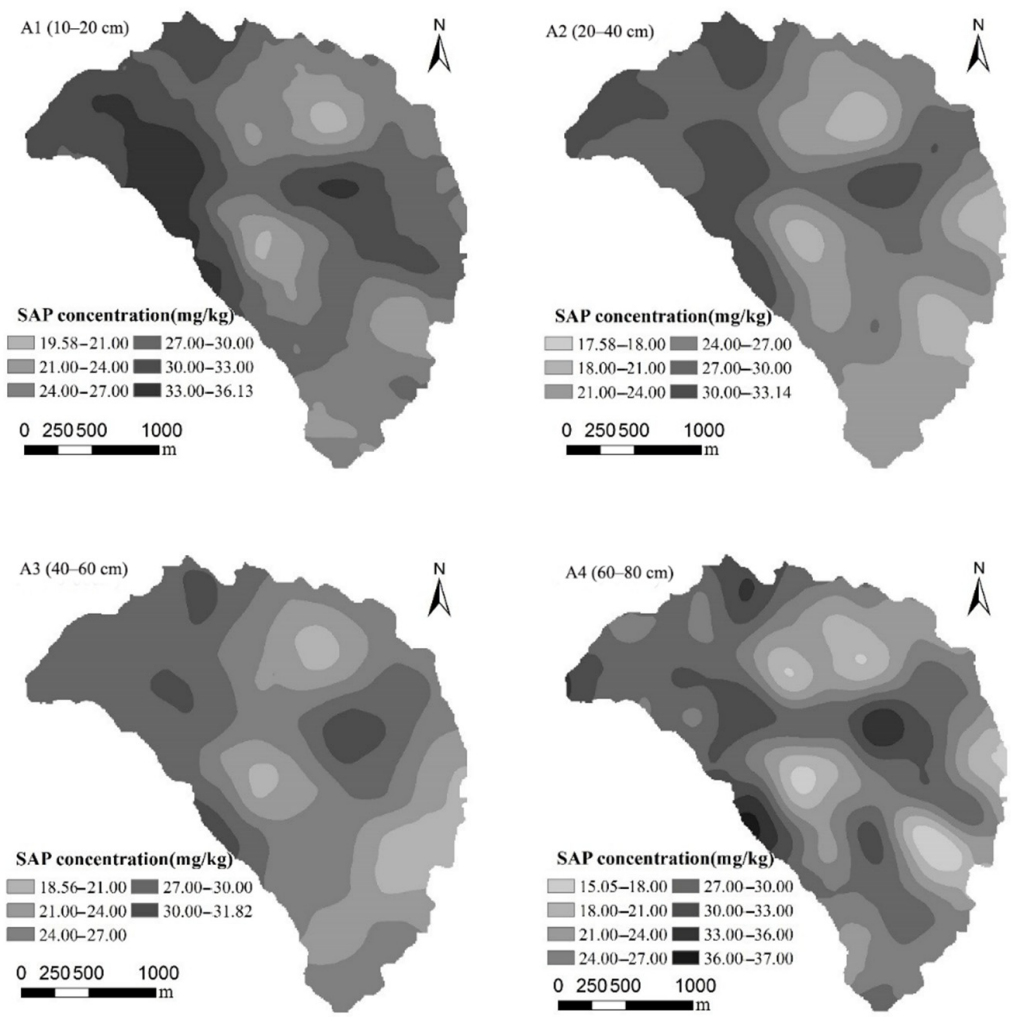

Figure 4. Cont. 


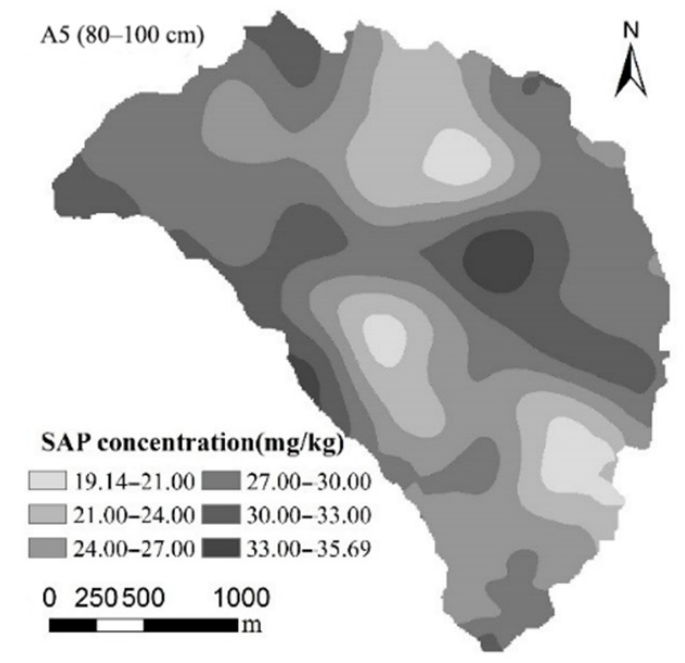

Figure 4. Spatial interpolation distribution of available phosphorus content in 0 20 cm soil layer (A1); Spatial interpolation distribution of available phosphorus content in $20 \sim 40 \mathrm{~cm}$ soil layer (A2); Spatial interpolation distribution of available phosphorus content in $40 \sim 60 \mathrm{~cm}$ soil layer (A3); Spatial interpolation distribution of available phosphorus content in $60 \sim 80 \mathrm{~cm}$ soil layer (A4); Spatial interpolation distribution of available phosphorus content in $80 \sim 100 \mathrm{~cm}$ soil layer (A5).

\subsection{SAP Density and Reserves under Different Land Uses}

According to Equations (2) and (3), the SAP density and reserves under different land uses in Wangmaogou Basin are calculated. According to the SAP density under different land uses (Table 5 and Figure 5), its maximum and minimum values appear in the terrace and the forestland. The SAP of layer A1 in different land uses varies greatly, which in descending order is: terrace $>$ dam $>$ sloping cropland $>$ grassland $>$ forestland. Shown by the variation coefficient of SAP density, the variations of SAP under five soil depths are weak, and the highest and lowest are discovered in terrace and grassland, respectively. Under different land uses, the SAP reserves at a depth of $0-100 \mathrm{~cm}$ are as follows: grassland $(123.64 t)>$ sloping cropland $(20.21 t)>$ check dam $(17.31 t)>$ terrace $(11.56 t)>$ forestland $(9.80 \mathrm{t})$. The total SAP reserves of $0-100 \mathrm{~cm}$ layer in the Wangmaogou Basin are $182.51 \mathrm{t}$.

Table 5. SAP density of layers under different land uses.

\begin{tabular}{|c|c|c|c|c|c|c|c|c|c|c|}
\hline \multirow{2}{*}{$\begin{array}{c}\text { Layer } \\
\text { Depth } \\
(\mathrm{cm})\end{array}$} & \multicolumn{2}{|c|}{ Terrace } & \multicolumn{2}{|c|}{ Grassland } & \multicolumn{2}{|c|}{ Forestland } & \multicolumn{2}{|c|}{$\begin{array}{l}\text { Sloping } \\
\text { Cropland }\end{array}$} & \multicolumn{2}{|c|}{ Check Dam } \\
\hline & $\begin{array}{l}\text { SAP } \\
\left(\mathrm{g} / \mathrm{m}^{2}\right)\end{array}$ & $\begin{array}{l}\text { CV } \\
(\%)\end{array}$ & $\begin{array}{l}\text { SAP } \\
\left(\mathrm{g} / \mathrm{m}^{2}\right)\end{array}$ & $\begin{array}{l}\text { CV } \\
(\%)\end{array}$ & $\begin{array}{l}\text { SAP } \\
\left(\mathrm{g} / \mathrm{m}^{2}\right)\end{array}$ & $\begin{array}{l}\text { CV } \\
(\%)\end{array}$ & $\begin{array}{l}\text { SAP } \\
\left(\mathrm{g} / \mathrm{m}^{2}\right)\end{array}$ & $\begin{array}{l}\text { CV } \\
(\%)\end{array}$ & $\begin{array}{l}\text { SAP } \\
\left(\mathrm{g} / \mathrm{m}^{2}\right)\end{array}$ & $\begin{array}{l}\text { CV } \\
(\%)\end{array}$ \\
\hline A1 & 7.91 & 9.51 & 7.08 & 3.77 & 6.44 & 5.52 & 7.16 & 8.47 & 7.77 & 7.02 \\
\hline $\mathrm{A} 2$ & 7.63 & 9.96 & 7.21 & 3.98 & 6 & 7.24 & 7.11 & 8.24 & 6.01 & 6.81 \\
\hline A3 & 7.97 & 8.89 & 7.2 & 4.27 & 6.43 & 8.17 & 6.6 & 8.6 & 7.07 & 6.49 \\
\hline A4 & 7.51 & 8.71 & 7.67 & 3.98 & 6.3 & 6.02 & 6.86 & 9.95 & 6.68 & 6.31 \\
\hline A5 & 7.98 & 8.83 & 7.95 & 3.56 & 6.63 & 7.16 & 6.65 & 8.6 & 6.67 & 7.32 \\
\hline $0-100 \mathrm{~cm}$ & 39 & 8.63 & 37.12 & 3.51 & 31.81 & 6.29 & 34.37 & 8.31 & 34.19 & 5.78 \\
\hline
\end{tabular}




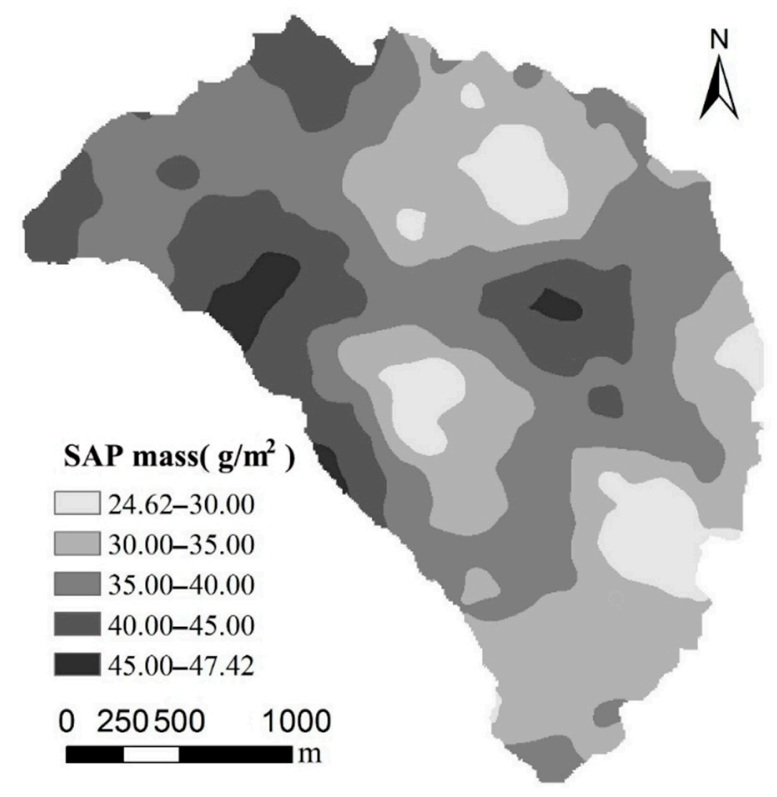

Figure 5. SAP density distribution in $0-100 \mathrm{~cm}$ soil in Wangmaogou Basin.

\section{Discussion}

The average SAP content in grassland is higher than in the other four land types, whereas that in sloping cropland is apparently lower than the other four land types. This indicates that the sloping cropland will increase after being converted into grassland, terrace, or check dam, which bears a resemblance to the studies of Xin [23] and Liu et al. [24], who found that the implementation of the ecological construction of the Loess Plateau effectively enhanced the role of soil organic carbon sinks, making the basin a repository for carbon and phosphorus. In addition, the SAP content in layer A1 of check dam is evidently higher than that of the other land types, and the content of organic matter and clay in the silt intercepted by check dam is usually higher than that of the source soil [25]. The soil clay content under the five types of lands is very low (the maximum value is less than $9 \%$ ), and there is no significant difference $(p>0.05)$ in the grain size under different land types. Because the dam is mainly distributed in the lower channels in the study area, fine soil particles on the slope are carried by rainfall and runoff and deposited on the dam. With a large specific surface area and charge density, the soil clay has a strong adsorption capacity for soil nutrients and can form relatively stable organic-inorganic composites with macromolecular organic substances (especially humus). These composites can form a more stable aggregate structure which has the effect of enhancing the accumulation of soil nutrients [26], and therefore the STP content of the dam is relatively high. This research result is consistent with that of Liu et al. [24], who gathered that the dam construction could intercept large amounts of sediment and phosphorus. In consequence, the construction of check dam in the Loess Plateau can significantly increase soil phosphorus content and increase soil fertility.

The variation of SAP is closely related to the complex terrain factors [27]. Changes in topography such as gradient, slope aspect, and altitude can lead to changes in an array of biological and abiotic activities [28], such as soil water content, microbial activity, water-heat balance, plant growth, and the amount of litters, thereby affecting SAP content. Previous studies have detected that there is an immense correlation between SAP and gradient, as well as a dramatic negative correlation between SAP and altitude. However, Wang et al. [29] found that soil nutrients could not be affected by the slope aspect. This article has discovered that the effects of topographic factors on SAP are different under different land use conditions, for which the reason is: the ecological construction measures in the Loess Plateau have caused a series of changes in vegetation coverage, soil properties, and water-heat balance, which is closely related to SAP content, thus reducing the influence of topographic factors on SAP and resulting in the different impacts of topography on SAP content in different land types. 


\section{Conclusions}

There are prominent differences in SAP at different soil depths and under various land uses. The average contents of SAP under five soil layers of A1, A2, A3, A4, and A5 are $28.19 \mathrm{mg} / \mathrm{kg}$, $27.26 \mathrm{mg} / \mathrm{kg}, 28.40 \mathrm{mg} / \mathrm{kg}, 27.66 \mathrm{mg} / \mathrm{kg}$, and $29.37 \mathrm{mg} / \mathrm{kg}$, and the spatial variability of SAP under the five soil layers is moderate. The average SAP content in the five land types in descending order is as follows: grassland $>$ terrace $>$ check dam $>$ sloping cropland $>$ forestland. The SAP content in terrace and dam of layer A1 are significantly higher than that of other land uses. In summary, converting the sloping cropland to grassland, terrace, or dam can raise SAP content.

The variation of SAP is closely related to topographic factors. Under different types of land use, the influencing factors are different: the altitude is significantly related to the SAP content in terrace, grassland, and sloping cropland $(p<0.01)$; the gradient is significantly related to the SAP content in grassland, forestland, and sloping cropland $(p<0.01)$; while the slope aspect only affects the SAP content in forestland $(p<0.05)$.

The spatial distribution of SAP under the five soil layers in Wangmaogou Basin is patchy. With the increase of depth, the available phosphorus content gradually decreases, and so does its change range. The highest values of SAP spatial distribution in the study area usually occur in grassland and dam. At the depth of five soil layers, the maximum and minimum values of SAP density appear in terrace and forestland, respectively. The SAP density varies significantly among different land types in layer A1, which in a descending order is: terrace $>$ check dam $>$ sloping cropland $>$ grassland $>$ forestland. The total SAP reserves of the 0-100 cm layer in the Wangmaogou Basin are $182.51 \mathrm{t}$.

Author Contributions: Conceptualization, S.C.; methodology, S.C. and Y.C.; software, G.K.; formal analysis, S.C.; data curation, H.W. and S.C.; writing-original draft preparation, S.C.; writing-review and editing, S.C. and G.K.; visualization, S.C.; proofreading, S.C.; supervision, Z.L. and Y.C.; project administration, S.C.; funding acquisition, Z.L. All authors have read and agreed to the published version of the manuscript.

Funding: This research was supported by the Research Fund of the State Key Laboratory of Ecohydraulics in Northwest Arid Region, Xi'an University of Technology (No. 2019KJCXTD-11) \& the National Natural Science Foundations of China "Regulation and long-term action mechanism of check dam on erosion energy in watershed" (No.52179043).

Institutional Review Board Statement: Not applicable.

Informed Consent Statement: Not applicable.

Data Availability Statement: Not applicable.

Conflicts of Interest: The authors state that they have no known competing financial interests or personal relationships that could affect the work described in this article.

\section{References}

1. Bureau, M.F.; Mederski, H.J.; Evans, C.E. The effect of phosphatic fertilizer material and soil phosphorus level on the yield and phosphorus uptake of soybeans. Agron. J. 1953, 45, 150-154. [CrossRef]

2. Mehnaz, K.R.; Keitel, C.; Dijkstra, F.A. Phosphorus availability and plants alter soil nitrogen retention and loss. Sci. Total Environ. 2019, 671, 786-794. [CrossRef] [PubMed]

3. Mao, R.; Zhang, X.-H.; Li, S.-Y.; Song, C.-C. Long-term phosphorus addition enhances the biodegradability of dissolved organic carbon in a nitrogen-limited temperate freshwater wetland. Sci. Total Environ. 2017, 605, 332-336. [CrossRef]

4. Gaind, S.; Pandey, A.K. Microbial biomass, P-nutrition, and enzymatic activities of wheat soil in response to phosphorus enriched organic and inorganic manures. J. Environ. Sci. Health Part B 2006, 41, 177-187. [CrossRef] [PubMed]

5. Meinikmann, K.; Hupfer, M.; Lewandowski, J. Phosphorus in groundwater discharge-A potential source for lake eutrophication. J. Hydrol. 2015, 524, 214-226. [CrossRef]

6. Daniel, T.C.; Sharpley, A.N.; Lemunyon, J.L. Agricultural phosphorus and eutrophication: A symposium overview. J. Environ. Qual. 1999, 27, 251-257. [CrossRef]

7. Cheng, S.D.; Li, Z.B.; Li, P.; Li, J. Experimental study on dynamic process of soil water-nutrient loss on slope with different pattern of grass. J. Soil Water Conserv. 2014, 28, 58-61. (In Chinese with English abstract) 
8. Yan, P.; Shen, C.; Fan, L.; Li, X.; Zhang, L.; Zhang, L.; Han, W. Tea planting affects soil acidification and nitrogen and phosphorus distribution in soil. Agric. Ecosyst. Environ. 2018, 254, 20-25. [CrossRef]

9. Junior, R.V.; Varandas, S.G.P.; Fernandes, L.S.; Pacheco, F.A.L. Groundwater quality in rural watersheds with environmental land use conflicts. Sci. Total Environ. 2014, 493, 812-827. [CrossRef]

10. Ordóñez-Fernández, R.; Rodríguez-Lizana, A.; Espejo-Pérez, A.J.; González-Fernández, P.; Saavedra, M.M. Soil and available phosphorus losses in ecological olive groves. Eur. J. Agron. 2007, 27, 144-153. [CrossRef]

11. Valera, C.A.; Valle, R.F., Jr.; Varandas, S.; Fernandes, L.; Pacheco, F. The role of environmental land use conflicts in soil fertility: A study on the Uberaba River basin, Brazil. Sci. Total Environ. 2016, 562, 463-473. [CrossRef]

12. Zhang, K.; Li, S.; Peng, W.; Yu, B. Erodibility of agricultural soils on the Loess Plateau of China. Soil Tillage Res. 2004, 76, 157-165. [CrossRef]

13. Fu, B.; Liu, Y.; Lü, Y.; He, C.; Zeng, Y.; Wu, B. Assessing the soil erosion control service of ecosystems change in the Loess Plateau of China. Ecol. Complex. 2011, 8, 284-293. [CrossRef]

14. Feng, X.; Fu, B.; Piao, S.; Wang, S.; Ciais, P.; Zeng, Z.; Lü, Y.; Zeng, Y.; Li, Y.; Jiang, X.; et al. Revegetation in China's Loess Plateau is approaching sustainable water resource limits. Nat. Clim. Chang. 2016, 6, 1019-1022. [CrossRef]

15. Ma, H.B.; Li, J.J.; He, X.Z.; Liu, X.Y.; Wang, F.G. The status and sediment reduction effects of level terrace in the Loess Plateau. Yellow River 2015, 37, 89-93, (In Chinese with English abstract).

16. Qiu, L.P. Change of Soil Quality and Its Regulation in Re-Vegetation Ecosystem of the Loess Plateau; Northwest A.\&F. University: Xianyang, China, 2007.

17. Fang, X.; Xue, Z.; Li, B.; An, S. Soil organic carbon distribution in relation to land use and its storage in a small watershed of the Loess Plateau, China. CATENA 2012, 88, 6-13. [CrossRef]

18. Deng, L.; Wang, G.-L.; Liu, G.-B.; Shangguan, Z.-P. Effects of age and land-use changes on soil carbon and nitrogen sequestrations following cropland abandonment on the Loess Plateau, China. Ecol. Eng. 2016, 90, 105-112. [CrossRef]

19. Liu, Q.; Xia, J.; Xie, W. Application of semi-variogram and Moran's I to spatial distribution of trace elements in soil: A case study in Shouguang County. Geomat. Inf. Sci. Wuhan Univ. 2011, 36, 1129-1133.

20. Xu, G.C.; Li, Z.B.; Li, P.; Liu, X.J.; Gao, H.D. Study on TN spatial variability of Yingwugou small watershed in Dan River. J. Soil Water Conserv. 2011, 25, 59-63. (In Chinese with English abstract)

21. Nielsen, D.R.; Bouma, J. Soil spatial variability. In Proceedings of the Workshop of the ISSS and the SSSA, Las Vegas, NV, USA, 30 November-1 December 1984; pp. 170-175.

22. Zhao, B.; Li, Z.; Li, P.; Xu, G.; Gao, H.; Cheng, Y.; Chang, E.; Yuan, S.; Zhang, Y.; Feng, Z. Spatial distribution of soil organic carbon and its influencing factors under the condition of ecological construction in a hilly-gully watershed of the Loess Plateau, China. Geoderma 2017, 296, 10-17. [CrossRef]

23. Xin, Z.; Qin, Y.; Yu, X. Spatial variability in soil organic carbon and its influencing factors in a hilly watershed of the Loess Plateau, China. Catena 2016, 137, 660-669. [CrossRef]

24. Liu, C.; Li, Z.; Dong, Y.; Nie, X.; Liu, L.; Xiao, H.; Zeng, G. Do land use change and check-dam construction affect a real estimate of soil carbon and nitrogen stocks on the Loess Plateau of China? Ecol. Eng. 2017, 101, 220-226. [CrossRef]

25. Sharpley, A.N. The selection erosion of plant nutrients in Runoff. Soil Sci. Soc. Am. J. 1985, 49, 1527-1534. [CrossRef]

26. Li, X.Y. Contents and Characteristic of Different from Organic Carbon and Nitrogen in Rhizosphere; Northwest A.\&F. University: Xianyang, China, 2011.

27. Liu, D.; Wang, Z.; Zhang, B.; Song, K.; Li, X.; Li, J.; Li, F.; Duan, H. Spatial distribution of soil organic carbon and analysis of related factors in croplands of the black soil region, Northeast China. Agric. Ecosyst. Environ. 2006, 113, 73-81. [CrossRef]

28. Wang, H.Q.; Hall, C.A.S.; Cornell, J.D.; Hall, M.H.P. Spatial dependence and the relationship of soil organic carbon and soil moisture in the Luquillo, Experimental Forest, Puerto Rico. Landsc. Ecol. 2002, 17, 671-684. [CrossRef]

29. Wang, Y.-Q.; Zhang, X.-C.; Zhang, J.-L.; Li, S.-J. Spatial variability of soil organic carbon in a watershed on the Loess Plateau. Pedosphere 2009, 19, 486-495. [CrossRef] 